\title{
SOME BETTER BOUNDS IN CONVERSES OF THE JENSEN OPERATOR INEQUALITY
}

\author{
JADRANKA Mićić, ZlatKo PAVIĆ AND Josip PEČARIĆ
}

\begin{abstract}
In this paper we study converses of a generalized Jensen's inequality for a continuous field of self-adjoint operators, a unital field of positive linear mappings and real values continuous convex functions. We obtain some better bounds than the ones calculated in a series of papers in which these inequalities are studied. As an application, we provide a refined calculation of bounds in the case of power functions.
\end{abstract}

Mathematics subject classification (2010): 47A63, 47B15.

Keywords and phrases: convex function, Jensen's operator inequality, Mond-Pečarić method, selfadjoint operators, positive linear mapping.

\section{REFERENCES}

[1] T. Furuta, J. Mićić Hot, J. PeČArić, Y. Seo, Mond-Pečarić Method in Operator Inequalities, Element, Zagreb, 2005.

[2] F. HANSEn, J. PeČARIĆ, I. Perić, A generalization of discrete Jensen's operator inequality and its converses, Hungarian-Croatian mathematical workshop, Debrecen, 2005.

[3] F. HANSEn, J. PeČARIĆ AND I. Perić, Jensen's operator inequality and its converses, Math. Scand. 100 (2007), 61-73.

[4] J. MIĆIĆ, Z. PAVIĆ AND J. PEČARIĆ, Jensen's inequality for operators without operator convexity, Linear Algebra Appl. 434 (2011), 1228-1237.

[5] J. MićIĆ, J. PeČARIĆ AND Y. SEO, Converses of Jensen's operator inequality, Oper. and Matr. 4 (2010), 385-403.

[6] J. E. Pečarić, F. Proschan, Y. L. Tong, Convex Functions, Partial Orderings, and Statistical Applications, Academic Press, San Diego, 1992.

[7] C. P. Niculescu, L. E. Persson, Convex Functions and Their Applications, Canadian Mathematical Society, 2006. 